\title{
Origins of Dissolved Organic Matter in Southern California Coastal Waters: Experiments on the Role of Zooplankton
}

\author{
R. W. Eppley ${ }^{1}$, S. G. Horrigan ${ }^{1}$, J. A. Fuhrman ${ }^{1}$, E. R. Brooks ${ }^{1}$, C. C. Price ${ }^{1}$ \\ and K. Sellner ${ }^{2}$ \\ ' Institute of Marine Resources, A-018, Scripps Institution of Oceanography, University of California, San Diego, La Jolla, \\ California 92093, USA \\ ${ }^{2}$ Academy of Natural Sciences of Philadelphia, 19th and the Parkway, Philadelphia, Pennsyivania 19103, USA
}

\begin{abstract}
The contribution of zooplankton to flows of dissolved organic carbon was studied for the food web of coastal plankton assemblages off Southern California, USA. Seawater samples including active macrozooplankton were labelled with ${ }^{14} \mathrm{CO}_{2}$. The time course of ${ }^{14} \mathrm{CO}_{2}$ incorporation into size fractions of the plankton and dissolved organic materials was determined. Changes in extracellular concentrations of free primary amines and dissolved saccharides were also measured. In addition, the time course of ${ }^{3} \mathrm{H}$-thymidine incorporation into bacteria was determined along with bacterial cell counts. By comparing carbon flows in samples with macrozooplankton and without macrozooplankton, we evaluated the role of macrozooplankton in the flux of carbon to bacteria and dissolved organic matter. One-half or more of the ${ }^{14} \mathrm{C}$-carbon in the bacterial size fraction could be due to small photosynthetic forms or the remains of microplankton disrupted by the filtration used in the size fractionation. Moreover, most of the carbon flowing to bacteria from the macrozooplankton was not labelled by ${ }^{14} \mathrm{C}$ and was proportional to the number of macrozooplankton. Conservative estimates of this unlabelled carbon flux to bacterial biomass due to macrozooplankton were 3 and $10 \%$ of the ${ }^{14} \mathrm{C}$ assimilated photosynthetically. Potential artefacts resulting from experimental manipulations are considered.
\end{abstract}

\section{INTRODUCTION}

Primary producers supply organic matter to natural bacterial communities, but to date the only mechanism for this transfer which has been studied extensively is the release of dissolved organic matter (DOM) from actively photosynthesizing cells. There has been significant speculation on other possible zooplanktonmediated mechanisms of DOM production from the primary producers (e.g. Berman and Holm-Hansen, 1974; Conover, 1979; Copping and Lorenzen, 1980; Bohrer and Sellner, in prep.; Williams, in prep.); however, little direct evidence has accumulated concerning these possible routes. The present study was prompted by the observation that the flux of organic carbon to bacteria is about $25 \%$ of the net particulate primary production in local waters (Fuhrman and Azam, 1980; A. F. Carlucci, pers. comm.). This value seemed higher than expected if the DOM flux were due entirely to the release of DOM by the phytoplank- ton. Two recent studies (Williams and Yentsch, 1976; Fuhrman et al., 1980) have concluded that DOM release from healthy photosynthesizing phytoplankton is not the sole important source of carbon for bacterial growth. The preliminary experiments reported here were designed to show whether macrozooplankton play a prominent role in the flux of organic matter to bacteria and DOM.

Earlier studies have shown excretion of DOM by zooplankton (Johannes and Webb, 1965, 1970; Corner and Newell, 1967; Webb and Johannes, 1967; Jawed, 1969; Eppley at al., 1973; Le Borgne, 1973; Mayzaud, 1973; Corner et al., 1976; Szyper et al., 1976). Further, phytoplankton cell breakage and loss of cellular contents during macrozooplankton grazing (sloppy feeding) have also been studied (Marshall and Orr, 1962; Conover, 1966; Lampert, 1978; Copping and Lorenzen, 1980; Bohrer and Sellner, in prep.). The laboratory experiments with single species of zooplankton and algae have indicated a loss of prey contents as DOC 
during feeding and handling, approximating 5-17\% of ingested prey carbon (Conover, 1966; Lampert, 1978; Copping and Lorenzen, 1980). Carnivorous zooplankton may release DOM and smaller particles in their feeding (Dagg, 1974). Moreover, DOM may be released from zooplankton feces (Lampert, 1978). Thus macrozooplankton may mediate a flux of DOC and/or small particles in at least 3 ways: excretory releases, breakage of prey during handling and feeding, and release from fecal material (Lampert, 1978). These 3 pathways were not independently assessed in our experimental design.

\section{METHODS}

Two experiments were carried out on board the RV 'New Horizon': the first. in which the nanoplankton were the predominant primary producers (hereafter called the 'nanoplankton experiment'), on 26-27 August 1979, and the second, in which the large-celled dinoflagellate Gymnodinium splendens dominated the flora (hereafter called the 'dinoflagellate experiment') on 11-12 May 1980. At daybreak, seawater was pumped from $20 \mathrm{~m}$ depth, within the mixed layer and just above the nutricline and chlorophyll maximum layer (nanoplankton experiment) or from $14 \mathrm{~m}$ depth, within the chiorophyll maximum (dinoflagellate experiment). The water was collected in 200-1 polyethylene vessels and mixed well with a stirring paddle. Ten l were dispensed into each of 6 (nanoplankton experiment) or 4 (dinoflagellate experiment) 20-1 polyethylene bottles. Macrozooplankton were removed during the filling of two of the bottles in each experiment by passing the water through $183 \mu \mathrm{m}$ mesh netting, i. e. 'screened treatment'. In the nanoplankton experiment, additional macrozooplankton were concentrated from about $100 \mathrm{l}$ of the seawater and an equal volume of the concentrate was added to each of two of the 20-I bottles. Two of the bottles in each experiment received water directly from the 200-1 vessels with no addition or removal of macrozooplankton. Radioactive carbon as ${ }^{14} \mathrm{C}$-bicarbonate was added to one of the 2 bottles for each treatment (to 1 bottle of unscreened water, to 1 bottle of screened water, and in the nanoplankton experiment, to 1 bottle with added macrozooplankton). One bottle of each set was used for chemical and biological analyses, the other for measurements involving the fluxes of radioactive carbon. No more than one-half the contents of a given bottle were used over the course of the experiments.

The stations were located $5 \mathrm{~km}$ off Dana Point, California, just beyond the shelf break (nanoplankton experiment) and $4 \mathrm{~km}$ off San Onofre, California on the shelf (dinoflagellate experiment).
The experiments commenced at first light when initial samples were taken and ${ }^{14} \mathrm{C}$ was added $(0.02 \mu \mathrm{Ci}$ $\mathrm{ml}^{-1}$ in nanoplankton experiment, $0.25 \mu \mathrm{Ci} \mathrm{ml^{-1 }}$ in dinoflagellate experiment). The $20-1$ bottles were covered with white cloth, reducing the sunlight irradiance by about $40 \%$. Irradiance within the bottles was not measured but was estimated to be less than $50 \%$ of incident. Temperature was controlled by a circulating sea water bath. The temperature of incubation was no more than $3 \mathrm{C}^{\circ}$ different from the temperature at the depth sampled.

Samples were removed immediately after adding the ${ }^{14} \mathrm{C}$ label (zero time, $\mathrm{t}_{0}$ ), and periodically until the following dawn to follow the time course of ${ }^{14} \mathrm{C}$ incorporation into particulate and 'dissolved' fractions and to assess changes in chlorophyll, dissolved free primary amines (DFPA), and dissolved saccharides (DSAC) (dinoflagellate experiment only), bacterial cell concentrations and rates of bacterial incorporation of ${ }^{3} \mathrm{H}$ thymidine. Samples for nutrient and total particulate carbon determinations were taken initially (nanoplankton experiment), and at sunset and at the following dawn (dinoflagellate experiment).

The replicate samples for ${ }^{14} \mathrm{C}$ and chlorophyll analyses were separated into size fractions by filtering sequentially through 0.6 and $0.2 \mu \mathrm{m}$ pore-size Nuclepore filters (nanoplankton experiment) or through 3, 1 , and $0.6 \mu \mathrm{m}$ pore-size Nuclepore filters and then through $\mathrm{PH}$ Millipore filters $(0.3 \mu \mathrm{m}$ nominal pore-size) (dinoflagellate experiment). The ${ }^{14} \mathrm{C}$-activity collected by the $0.2 \mu \mathrm{m}$ (nanoplankton experiment) or by the 0.6 $\mu \mathrm{m}$ (dinoflagellate experiment) Nuclepore filters and by the PH Millipore filter is assumed to be largely associated with bacteria.

Analytical methods followed procedures described in several reports: chlorophyll and phaeopigments by fluorometry and nutrients by spectrophotometric methods in Strickland and Parsons (1972); POC according to Sharp $(1974) ;{ }^{14} \mathrm{C}$ on filters by liquid scintillation counting with external and internal $\left({ }^{14} \mathrm{C}\right.$ toluene) standardization; bacterial counts by epifluorescence microscopy (Hobbie et al., 1977); thymidine incorporation of replicate samples as given in Fuhrman et al. (1980), and DFPA (modified from North, 1975) and DSAC (Burney and Sieburth, 1977). The ${ }^{14} \mathrm{C}$ labelled DOM (filtrate of smallest pore-size filter) was assessed after acidifying and bubbling with air to remove ${ }^{14} \mathrm{CO}_{2}$. ${ }^{14} \mathrm{C}$-data for size fractions were corrected by substracting time zero values.

Samples for phytoplankton were collected initially and were preserved for microscopic examination using formalin buffered with sodium borate. Macrozooplankton were collected from the incubated samples at the end of each experiment for identification and enumeration and for assessment of ${ }^{14} \mathrm{C}$-activity. 
The pump used for sampling was a large-capacity diaphragm pump with $10-\mathrm{cm}$ diameter hosing. It is routinely used at Scripps Institution of Oceanography in collecting zooplankton (Star and Mullin, 1979). For the dinoflagellate experiment, the intake of the pump hose was attached to a rosette sampler (General Oceanics, Inc.) equipped with a Seamartech submersible fluorometer and CTD. Data were displayed on deck during the lowering using an HP-system 45 minicomputer. The data acquisition and processing systems were designed and constructed by C. R. Booth.

\section{RESULTS}

\section{Conceptual Model}

The experimental approach in the present study was vегу simple compared to those used by zooplanktologists in radioisotope studies of feeding mechanisms and behavior. Typically, experiments begin with pre-labelled prey organisms. In the present study, the isotope was added at the beginning of the experiment; a prelabelling period might have involved species shifts in prey populations due to the relatively long incubations required to achieve uniform labelling.

Conover and Francis (1973) have shown how complex the kinetic analysis of carbon flows in the food web can be as the number of labelled compartments increases. In the present case, neither the effective number of compartments nor the measurement of the time course of labelling in each could be estimated. Nor can it be assumed that a steady state was reached during the 24-h experiments. The approach must be considered opportunistic, using filter screens to isolate size fractions which very roughly approximate phytoplankton (plus microzooplankton and bacteria associated with particles), a fraction containing most of the free-living bacteria (and undoubtedly a few small flagellates and cyanobacteria), and a 'dissolved' fraction. Theoretically, if sloppy feeding, or the other modes of zooplankton-mediated DOC production, are quantitatively important pathways, then one would

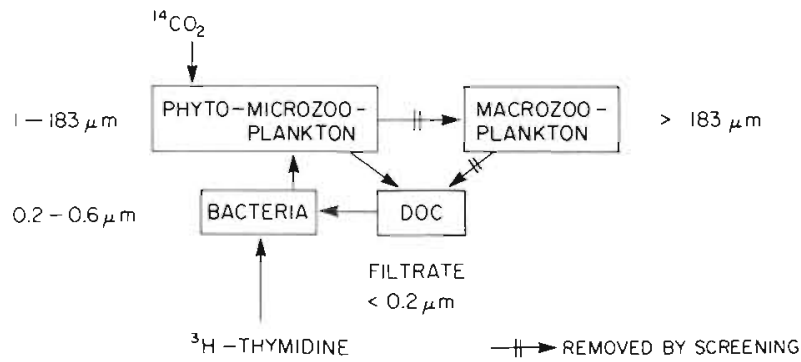

Fig. 1. Conceptual model of the experiments. Arrows indicate assumed carbon flows. Filter screen pore sizes used to define the size classes of organisms and DOC are indicated expect a higher carbon flux per unit phytoplankton to the dissolved and bacterial fractions when zooplankton are present than when they are absent.

The measurements were based on the conceptual model of carbon flows among the plankton shown in Fig. 1. The photosynthetic phytoplankton assimilate carbon dioxide. The phytoplankton are prey for microzooplankton and both are grazed by macrozooplankton. Dissolved organic carbon is released to the seawater in association with both processes. The DOC is assimilated by bacteria and the bacteria are grazed by microzooplankton. Removal of macrozooplankton before the experiments deletes their contribution to the pool of DOC via predator grazing and metabolism.

Fig. 1 also summarizes the experimental measurements scheme. The flow of ${ }^{14} \mathrm{C}$-carbon over time into the phytoplankton + microzooplankton, bacteria, and DOC compartments was followed, using the approximate size-class separations afforded by filter screens. Size-fractionation procedures provide imperfect separations not only due to overlapping size classes of the organisms but also due to bacteria associated with larger particles (Azam and Hodson, 1977). Mechanical disruption of particles during filtration leads in general to anomalously high recoveries in the smaller size fractions (Wheeler et al., 1977) and perhaps lysis of phytoplankton cells (Mopper and Lindroth, unpubl.).

As an independent assessment of bacterial activity

Table 1. Macrozooplankton counts. The ${ }^{14} \mathrm{C}$-carbon content was assessed for individual species in the nanoplankton experiment only. S: supplemented treatment; U: unscreened treatment

\begin{tabular}{|c|c|c|c|c|}
\hline \multirow[b]{2}{*}{ Organism } & \multicolumn{2}{|c|}{$\begin{array}{l}\text { Number } \\
\text { in } 10 \mathrm{l}\end{array}$} & \multicolumn{2}{|c|}{$\begin{array}{l}{ }^{14} \mathrm{C} \text {-carbon } \\
\text { content after } \\
24 \mathrm{~h}(\mathrm{ng})\end{array}$} \\
\hline & $\mathrm{S}$ & $\mathrm{U}$ & $\mathrm{S}$ & U \\
\hline & \multicolumn{4}{|c|}{ Nanoplankton experiment } \\
\hline Paracalanus parvus & 30 & 7 & 192 & 90 \\
\hline Oithona sp. & 107 & 20 & 30 & 13 \\
\hline Acartia tonsa & 36 & 5 & 29 & 0 \\
\hline Others & 24 & 3 & 132 & 0 \\
\hline Total & $\overline{197}$ & $\overline{35}$ & $\overline{383}$ & $\overline{103}$ \\
\hline & Din & igell & expe & iment \\
\hline \multicolumn{5}{|l|}{ Acartia tonsa } \\
\hline Cl, CII & & 10 & & \\
\hline adult & & 5 & & \\
\hline Paracalanus parvus & & 8 & & \\
\hline Euterpina acutifrons & & 1 & & \\
\hline Calanus pacificus nauplius & & 8 & & \\
\hline Corycaeus anglicus & & 7 & & \\
\hline Foraminifera & & 6 & & \\
\hline Oithona sp. & & 1 & & \\
\hline Invertebrate larvae & & 2 & & \\
\hline Total & & $\overline{48}$ & & $\overline{12,800}$ \\
\hline
\end{tabular}


in response to flows of utilizable DOC from phytoplankton, ${ }^{3} \mathrm{H}$-thymidine incorporation into acid-insoluble material, reflecting bacterial DNA synthesis, was measured. Thymidine incorporation has been examined extensively in the euphotic zone of Southern California coastal waters; (Fuhrman et al., 1980; Fuhrman and Azam, 1980). Because much of this growth occurs at the expense of DOC (Fuhrman and Azam, 1980), the thymidine incorporation rate can be used to estimate the total flux of DOC to the bacteria.

\section{Evidence of Grazing by Macrozooplankton}

In the nanoplankton experiment, chlorophyll a concentrations declined from $0.27 \mu \mathrm{g} \mathrm{I}^{-1}$ initially to $0.16 \mu \mathrm{g} \mathrm{l}^{-1}$ by macrozooplankton-enriched treatments. Ambient macrozooplankton densities were low with the small herbivorous copepod Paracalanus parvus ( 7 individuals in $10 \mathrm{l}$ ), and Oithona sp. (20 ind. in $10 \mathrm{l}$ ) predominant (Table 1); therefore, there was low grazing pressure in the unenriched sample. The macrozooplankton-supplemented water contained $30 \mathrm{P}$. parvus and 107 Oithona sp. in $10 \mathrm{l}$.

At the end of the 24-h incubation period, the animals in the nanoplankton experiment contained approximately $0.1 \%$ of the amount of ${ }^{14} \mathrm{C}$ incorporated into the

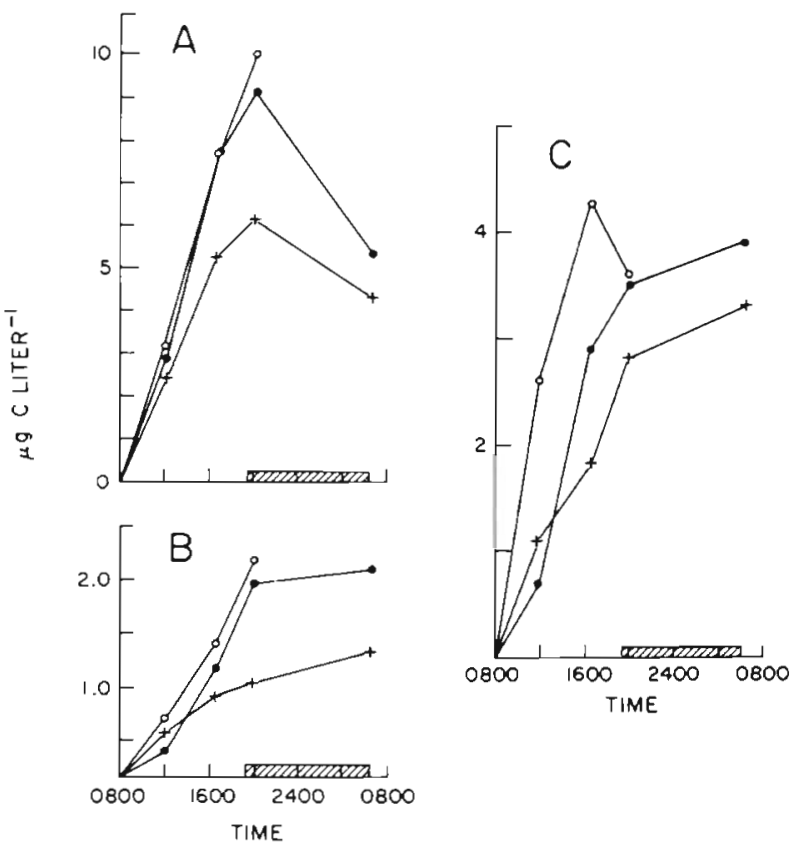

Fig. 2. Time course of ${ }^{14} \mathrm{C}$ incorporation into size fractions in the nanoplankton experiment. (A) Activity retained on $0.6 \mu \mathrm{m}$ Nuclepore filter. (B) Activity passing $0.6 \mu \mathrm{m}$ filter but retained by $0.2 \mu \mathrm{m}$ Nuclepore filter. (C) Activity passing $0.2 \mu \mathrm{m}$ filter + macrozooplankton-supplemented water; open circles: unscreened water; solid circles: water passed

through $183 \mu \mathrm{m}$ netting before starting the experiment
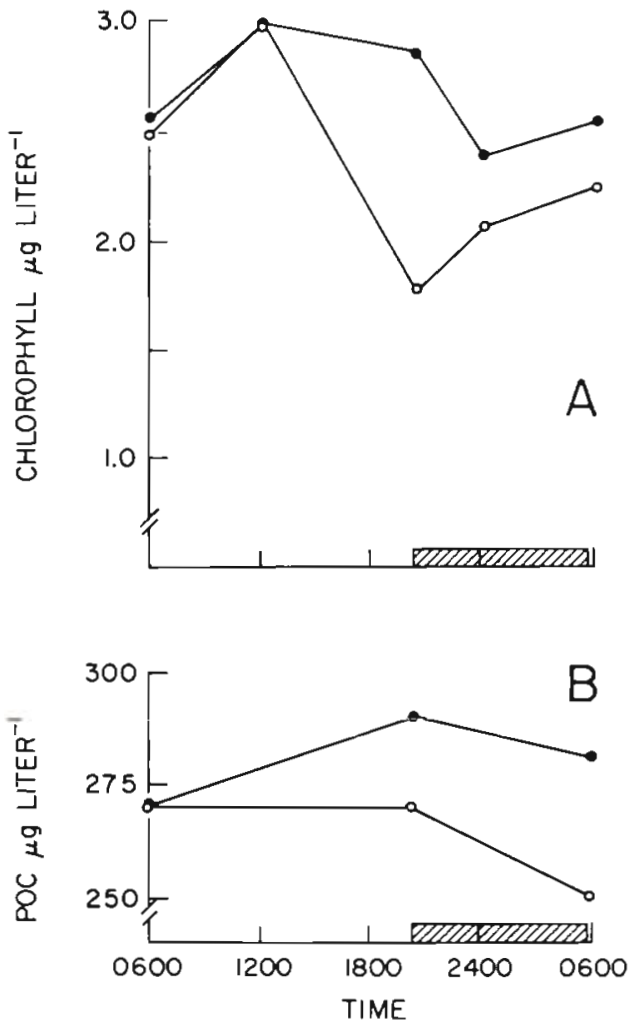

Fig. 3. Time course of change in chlorophyll a (A) and POC (B) in the dinoflagellate experiment. Open circles: unscreened water; solid circles: water passed through $183 \mu \mathrm{m}$ netting before starting the experiment

phytoplankton $(>0.6 \mu \mathrm{m})$ in the unscreened sample and $0.9 \%$ in the macrozooplankton-enriched sample. Examination of the ${ }^{14} \mathrm{C}$-activities in the 0.6 and $0.2 \mu \mathrm{m}$ fractions as well as the filtrate indicated reduced carbon fixation in all 3 pools in the macrozooplanktonsupplemented samples (Fig. 2). There was little difference evident in ${ }^{14} \mathrm{C}$-activities between the 3 pools in the screened and unscreened samples. These data indicate that grazing pressure was low and was obvious only when predator densities were increased substantially over ambient levels.

In the dinoflagellate experiment, decreases in chlorophyll a (Fig. 3A) and POC (Fig. 3B) suggested greater zooplankton grazing than observed in nanoplankton experiment. For example, chlorophyll decreased from $2.98 \mu \mathrm{g} \mathrm{l}^{-1}$ at $1200 \mathrm{~h}$ to $1.78 \mu \mathrm{g} \mathrm{l}^{-1}$ at $2000 \mathrm{~h}$ in the unscreened samples. Differences in these pools appeared by sunset and persisted through the following morning (Fig. 3). The differences in chlorophyll a between treatments with and without macrozooplankton were not reflected in phaeopigment changes, however. The latter remained less than $0.4 \mu \mathrm{g}$ $1^{-1}$ throughout the experiment with no temporal trend in any of the size fractions or the combined total. Total bottle contents were not examined for copepod fecal 
pellets and they would be too rare to occur in the small $(100 \mathrm{ml})$ samples removed for pigment analysis. There was no significant difference noted between ${ }^{14} \mathrm{C}$-fixation rates of phytoplankton in screened and unscreened samples (Fig. 4), indicating little effect of zooplankton grazing on rate of carbon incorporation by phytoplankton. Numbers of macrozooplankton in the unscreened samples were nevertheless higher than in the nanoplankton experiment. Paracalanus parrus, Acartia tonsa and copepod nauplii numbered 31 in 101 (Table 1). The ${ }^{14} \mathrm{C}$-carbon content of the animals was $1.1 \%$ of that of the particulate matter after $28 \mathrm{~h}$, considerably higher than in the nanoplankton experiment (Table 1).

\section{Flux of Carbon Between Particulate and Dissolved Pools}

Since ${ }^{14} \mathrm{C}$-fixation rates were lower in the macrozooplankton-supplemented samples than in the screened or unscreened samples of the nanoplankton experiment, one might expect activities of the $0.2 \mu \mathrm{m}$ fraction and $\mathrm{DO}^{14} \mathrm{C}$ to increase. This was not observed; activities in these 2 fractions were lower than recorded for either the screened or unscreened samples. When

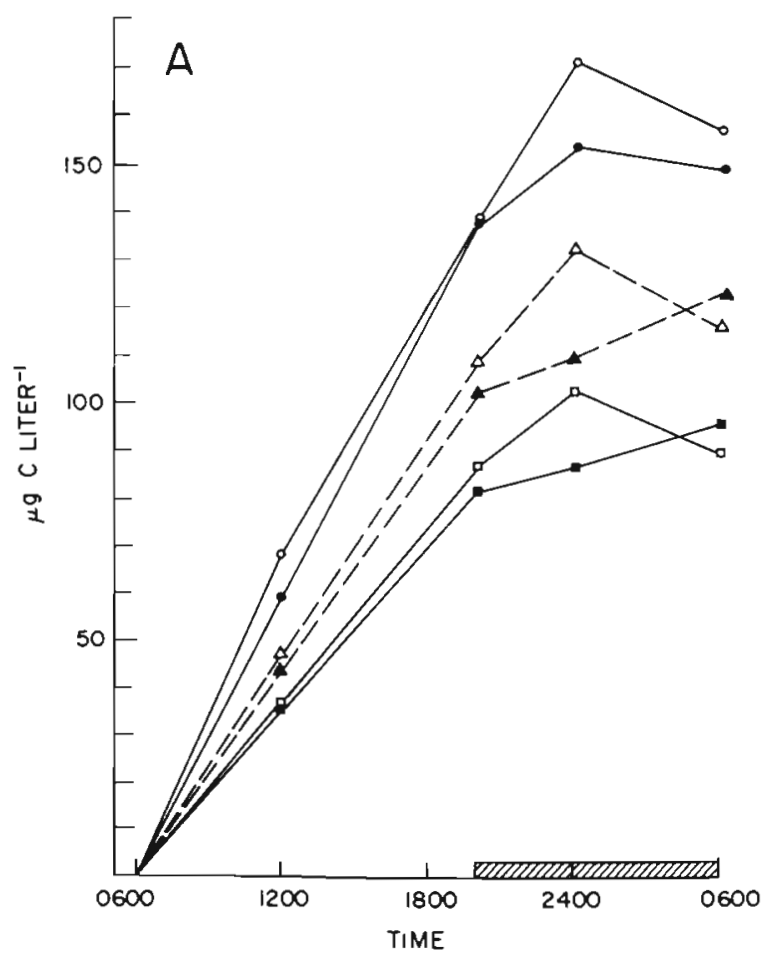

the ${ }^{14} \mathrm{C}$-activities in the filtrate and the bacterial size fraction $(0.2 \mu \mathrm{m})$ were normalized to the activity of the phytoplankton size fraction $(>0.6 \mu \mathrm{m})$, the activities of the $\mathrm{DO}^{14} \mathrm{C}$ and bacteria were initially greater in the presence of macrozooplankton than in its absence (1200 h, Table 2). The ratios rapidly approached similar values over the remainder of the experiments. If macrozooplankton grazing resulted in the production of DOM, the ratios would fall in the order of macrozooplankton-supplemented $>$ unscreened $>$ screened for both bacteria and $\mathrm{DO}^{14} \mathrm{C}$. Therefore, the presence of macrozooplankton did not result in enhanced concentrations of $\mathrm{DO}^{14} \mathrm{C}$ over most of the $24-\mathrm{h}$ incubation period.

A time course of carbon flow into the various size fractions in the dinoflagellate experiment is shown in Fig. 4. The total was about $140 \mu \mathrm{g} \mathrm{C} \mathrm{l}^{-1}$ during the $14-\mathrm{h}$

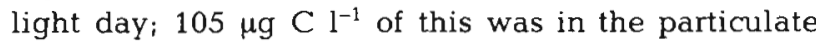
fractions (Fig. $4 \mathrm{~A}$ ). The particulate carbon assimilation per weight of chlorophyll a (the productivity index) over the 14 -h light period was $3.0 \mu \mathrm{g} \mathrm{C}(\mu \mathrm{g} \mathrm{Chl} \mathrm{a})^{-1} \mathrm{~h}^{-1}$, a value typical of local surface waters. Carbon incorporation into the bacterial size fraction $(>0.2 \mu \mathrm{m})$ and the 'dissolved' organic ${ }^{14} \mathrm{C}$-carbon (filtrate) data are shown in Fig. 4B, indicating no significant differences in labelled $\mathrm{DOM}$ flux to the bacteria or $\mathrm{DO}^{14} \mathrm{C}$ pool through zooplankton grazing even though reduction in chlorophyll $a$ and POC were evident.

The changes in concentration of DFPA and DSAC were determined over the incubation period (Fig. 5). In the screened sample, DFPA concentrations increased from 19.3 to $23.8 \mu \mathrm{g}$ gly-equiv $\mathrm{I}^{-1}$ during daylight

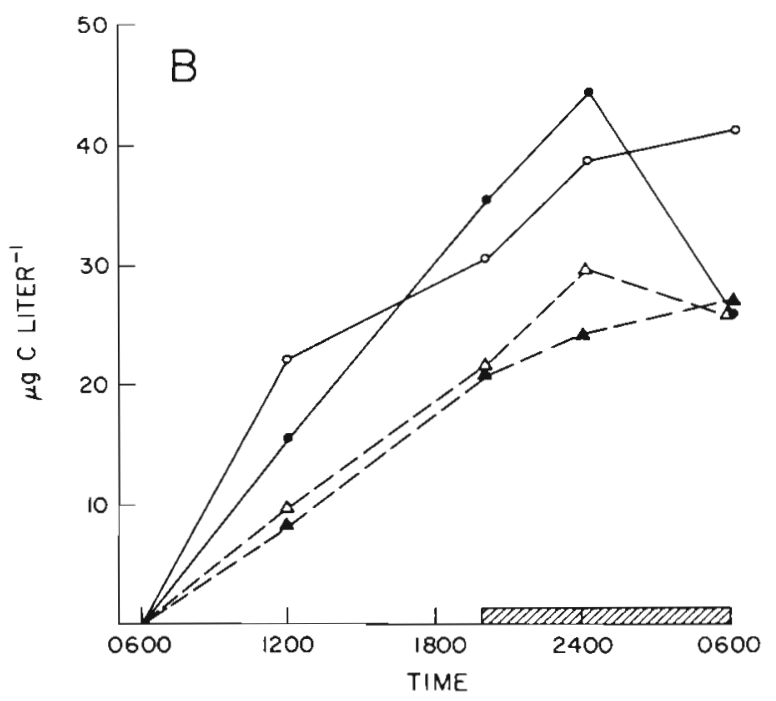

Fig. 4. Time course of ${ }^{14} \mathrm{C}$ incorporation into size fractions in the dinoflagellate experiment. (A) Total (particulate + dissolved) incorporation (circles), incorporation into particles $>0.2 \mu \mathrm{m}$ (triangles), and incorporation into particles $>1 \mu \mathrm{m}$ (squares); open symbols: unscreened water containing macrozooplankton; solid symbols: water passed through $183 \mu \mathrm{m}$ netting before starting the experiment. (B) Incorporation into DOC (circles, as above) and incorporation into particles passing a $1 \mu \mathrm{m}$ Nuclepore filter but retained on a $0.2 \mu \mathrm{m}$ filter (triangles, as above) 
(0600-2000 h), then declined in the nocturnal period to $15.7 \mu g$ gly-equiv $1^{-1}$. The concentrations of DSAC may have also declined over the study period (Fig. 5B) although the data were quite variable. In the unscreened sample, initial DFPA concentrations were $26.1 \mu \mathrm{g}$ gly-equiv $\mathrm{l}^{-1}$. A small nocturnal loss of DSAC was also observed (nonsignificant).

\section{Bacterial Cell Counts}

The epifluorescense counts of free-living bacteria (Table 3 ) were initially about $10^{9} \mathrm{l}^{-1}$. Counts declined in the nanoplankton experiment over the first hours and remained low in the unscreened and screened treatments. At the last 3 sampling times, counts were highest in the zooplankton-supplemented treatment. Counts were more uniform with time in the dinoflagellate experiment with perhaps a slight rise after $24 \mathrm{~h}$ $(0600 \mathrm{~h})$, indicating a relatively small increase in bacteria.

Table $2 .{ }^{14} \mathrm{C}$ activity in 'dissolved' and 'bacterial' size fractions normalized to that in phytoplankton size fractions. Screened: water passed through $183 \mu \mathrm{m}$ net before incubation; supplemented: additional zooplankton added before incubation. ${ }^{14} \mathrm{C}$ flux mediated by zooplankton is implied if values follow the order supplement $>$ unscreened $>$ screened at each sampling time

\begin{tabular}{|c|c|c|c|c|}
\hline \multirow{2}{*}{$\underbrace{\text { Treatment }}_{\text {Nanoplankton experiment }}$} & \multicolumn{4}{|c|}{ Time } \\
\hline & 1200 & 1640 & 2000 & 0630 \\
\hline & \multicolumn{4}{|c|}{$\begin{array}{c}\text { Bacterial fraction/ } \\
\text { phytoplankton fraction }\end{array}$} \\
\hline supplemented & 0.17 & 14 & 14 & .27 \\
\hline unscreened & 17 & .16 & .20 & $\begin{array}{c}\text { no } \\
\text { sample }\end{array}$ \\
\hline \multirow[t]{2}{*}{ screened } & .09 & .13 & .20 & 36 \\
\hline & \multicolumn{4}{|c|}{$\begin{array}{l}\text { Dissolved fraction } \\
\text { phytoplankton fraction }\end{array}$} \\
\hline supplemented & 0.46 & .34 & .46 & 77 \\
\hline unscreened & .81 & .55 & .35 & $\begin{array}{c}\text { no } \\
\text { sample }\end{array}$ \\
\hline screened & .24 & .37 & .38 & .73 \\
\hline \multirow[t]{2}{*}{ Dinoflagellate experiment } & 1200 & 2000 & 2400 & 0600 \\
\hline & \multicolumn{4}{|c|}{$\begin{array}{c}\text { Bacterial fraction/ } \\
\text { phytoplankton fraction }\end{array}$} \\
\hline unscreened & 0.28 & .18 & .29 & .28 \\
\hline \multirow[t]{2}{*}{ screened } & .24 & .26 & .28 & .29 \\
\hline & \multicolumn{4}{|c|}{$\begin{array}{l}\text { Dissolved fraction/ } \\
\text { phytoplankton fraction }\end{array}$} \\
\hline unscreened & 0.62 & .35 & .38 & .46 \\
\hline screened & .44 & .44 & .52 & .27 \\
\hline
\end{tabular}

\section{Bacterial Activity}

The rate of incorporation of tritiated thymidine increased over time in both experiments (Fig. 6). Highest rates occurred in the treatments with zooplankton present. The order of rates in the nanoplankton experiment was zooplankton-supplemented $>$ unscreened $>$
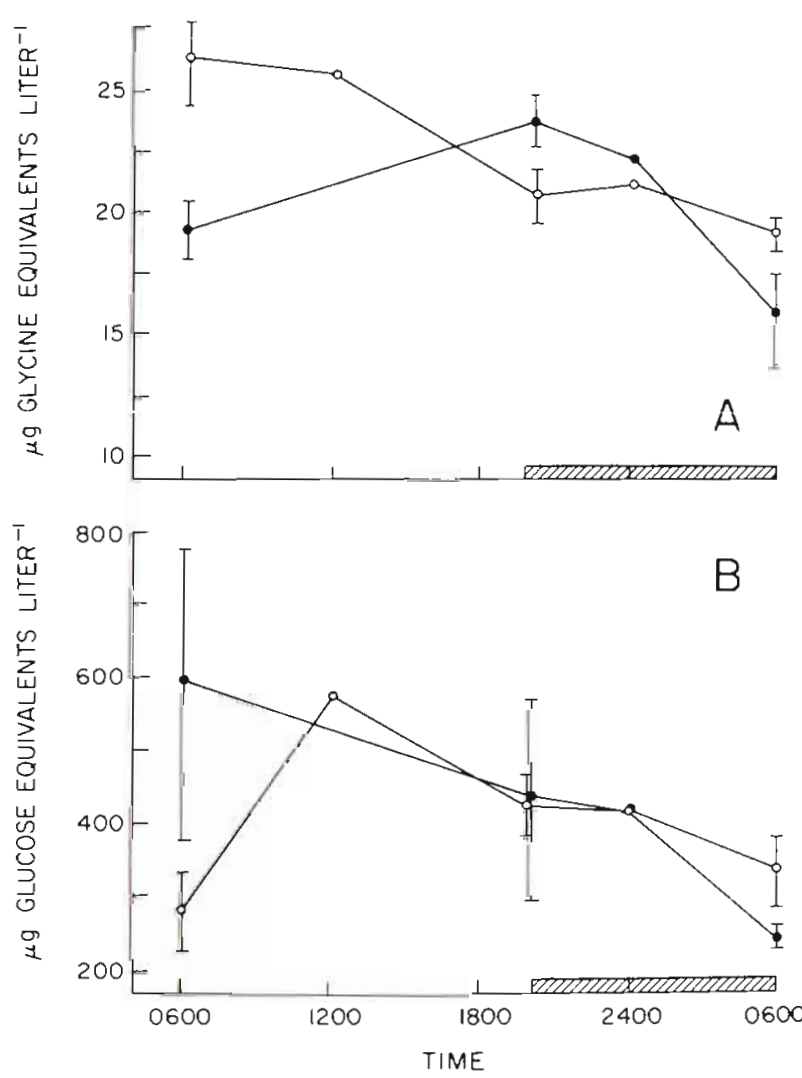

Fig. 5. Time course of change in dissolved free primary amines (A) and dissolved saccharides $(B)$ in the dinoflagellate experiment. Open circles: unscreened water with macrozooplankton; solid circles: water with macrozooplankton removed before starting the experiment

screened, and in the dinoflagellate experiment, unscreened $>$ screened. These higher incorporation rates in the second experiment were paralleled by continuous decrease in DFPA and to a lesser degree, DSAC, in the unscreened samples over the experimental period (Figs. 5A, B).

The thymidine incorporation rates increased over time in these experiments (Fig. 6) from initial values about $\leq 1 \times 10^{-10}$ moles $l^{-1} \mathrm{~d}^{-1}$ to $14-36 \times 10^{-10}$ moles $\mathrm{l}^{-1} \mathrm{~d}^{-1}$. The latter rates are high compared to rates measured previously in water samples from the Southern California Bight (SCB): averages of many samples were $1.08 \times 10^{-10}$ moles $l^{-1} \mathrm{~d}^{-1}$ on cruise SCBS-14 and $1.04 \times 10^{-10}$ on cruise SCBS-15 (Fuhrman et al., 1980). 
Table 3. Bacterial cell counts expressed as $10^{9} \mathrm{1}^{-1}$

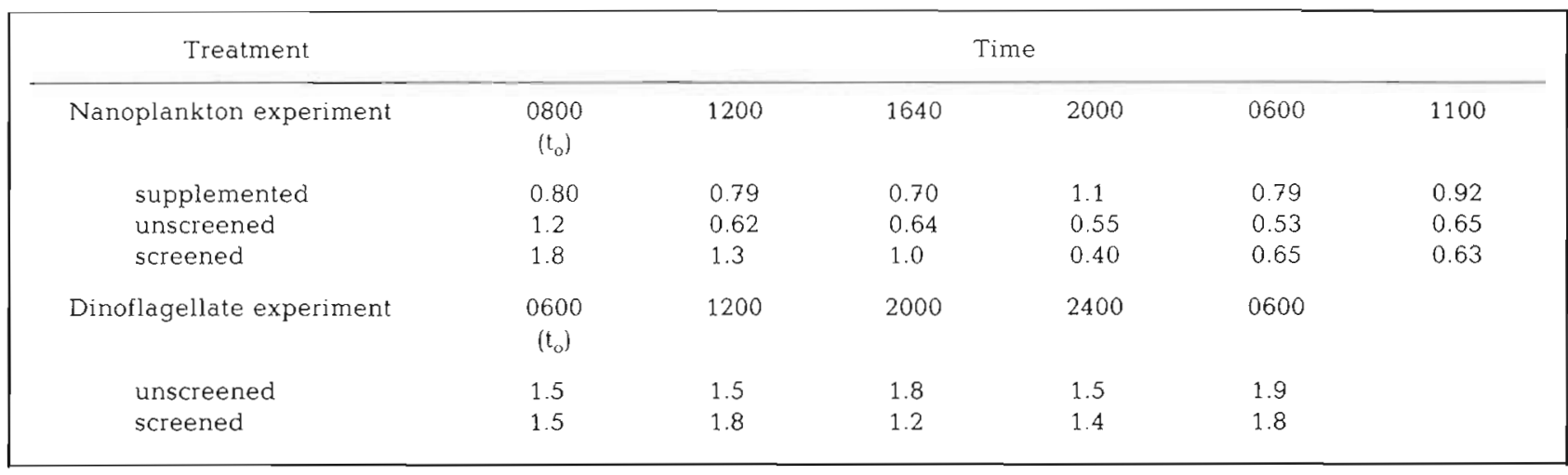

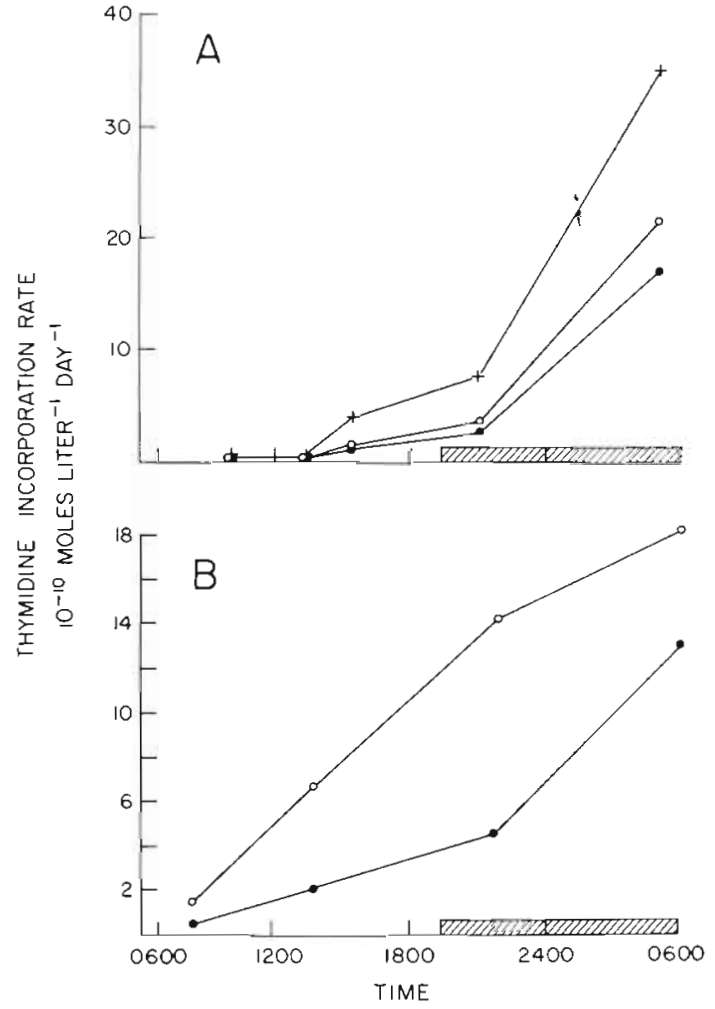

Fig. 6. Time course of rate of thymidine incorporation in the nanoplankton experiment (A) and the dinoflagellate experiment (B). Plotted times are midpoints of $3 \mathrm{~h}$ incubations of subsamples. Each represents the mean of duplicates; precision was quite good, with the range of duplicates averaging $2.8 \%$ of the mean. + zooplankton supplemented treatment; open circles: unscreened water; solid circles: macrozooplankton removed before starting the experiment

Thus the high rates at the end of both experiments were unique to the experimental enclosures.

The thymidine incorporation rates reflect DNA synthesis and thus serve, when normalized to the bacterial cell counts, as an index of bacterial growth rate. In the data of Fuhrman et al. (1980), thymidine incorporation rate per cell averaged 3.54 and $1.68 \times 10^{-19}$ moles cell-1 $\mathrm{d}^{-1}$ for cruises SCBS 14 and 15 , respectively. In the present work, rates were less than these average values for about $6 \mathrm{~h}$, then exceeded them, reaching the highest value $\left(45 \times 10^{-19}\right.$ moles cell ${ }^{-1} \mathrm{~d}^{-1}$ ) after $24 \mathrm{~h}$ in the zooplankton-supplemented treatment of nanoplankton experiment (Fig. 6). Such a rate would correspond to about 1 to $6 \times 10^{-14} \mathrm{~g} \mathrm{C}$ cell ${ }^{-1} \mathrm{~d}^{-1}$. If the cellular carbon content were $10^{-14} \mathrm{~g} \mathrm{C}$ cell $^{-1}$ (Fuhrman and Azam, 1980), then the specific growth rate would be $1-6 \mathrm{~d}^{-1}$. Since this high activity is atypical of the local waters, we conclude that it represents a response to the experimental conditions. It implies a flux of unlabelled DOC to bacteria and a bacterial response not reflected in either the bacterial counts or the flux of ${ }^{14} \mathrm{C}$ into the bacterial or DOC compartments.

\section{DISCUSSION}

\section{Grazing}

Differences in the ingestion of phytoplankton prey by the zooplankton assemblages present during the 2 experiments were perhaps a function of the different plankton communities present. In the first, Paracalanus parvus and Oithona sp. were the 2 predators for a nanoplankton-dominated phytoplankton community. Significant grazing pressure was only observed in the macrozooplankton-supplemented samples; at in situ plankton densities, no differences in ${ }^{14} \mathrm{C}$-fixation in the $>0.6 \mu \mathrm{m}$ fraction were observed between the $183 \mu \mathrm{m}$ screened and unscreened samples. Since P. parvus is primarily herbivorous, removal of these predators by screening through $183 \mu \mathrm{m}$ netting might have reduced competition for microzooplankton feeding on the limited nanoplankton biomass, yielding similar ${ }^{14} \mathrm{C}$ incorporation rates for the macrozooplankton-microzooplankton-phytoplankton (unscreened) and the microzooplankton-phytoplankton (screened) samples (Fig. 2).

In the second experiment, Paracalanus parvus and 
Acartia tonsa were the chief macrozooplankton herbivores and the phytoplankton were dominated by the large-celled dinoflagellate Gymnodinium splendens. On the basis of its concentration and large size $(40-50 \mu \mathrm{m})$, relative to the small nanoplankton of the nanoplankton experiment, one might have expected higher ingestion rates due to size-selective feeding in the macrozooplankton, but microscopic observations suggested that grazing largely avoided G. splendens (cf. Fiedler and Huntley, 1981). In fact, grazing did occur in the dinoflagellate experiment, as noted by the declines in chlorophyll and POC over the $24 \mathrm{~h}$ incubation period, but appeared to be concentrated on smaller forms. The ${ }^{14} \mathrm{C}$ content of the animals was considerably higher in the dinoflagellate experiment than in the nanoplankton experiment.

\section{Flux of Carbon}

The role of zooplankton in the turnover of phytoplankton carbon is characterized in Fig. 1. Since zooplankton grazing was noted in both experiments, a decline in phytoplankton ${ }^{14} \mathrm{C}$-carbon would be expected to appear as an increase in zooplankton radioactivity, in the activity of the pool of $\mathrm{DO}^{14} \mathrm{C}$, and/ or in bacterial radioactivity. The ${ }^{14} \mathrm{C}$-incorporation in Paracalanus parvus and Oithona sp. was minimal in the nanoplankton experiment, at $10-38 \mathrm{ng} \mathrm{C} \mathrm{l}^{-1} 24 \mathrm{~h}^{-1}$. The bacterial and dissolved fractions of the unscreened and supplemented samples of the nanoplankton experiment had initial higher ${ }^{14} \mathrm{C}$-activities than the screened sample (Table 2).
The higher ${ }^{14} \mathrm{C}$-ratios observed for the unscreened and supplemented samples from the nanoplankton experiment $(1200 \mathrm{~h})$ were also supported by the thymidine incorporation data. In both samples with macrozooplankton, higher thymidine incorporation rates were observed relative to the screened samples. That is, bacterial activity was related to the number of macrozooplankton present. Because thymidine incorporation is an indicator of DNA synthesis and hence growth, incorporation must also reflect the supply of labile substrate to the microflora. These results suggest that zooplankton grazing resulted in enhanced carbon flow to the bacterial community, although a large part of the carbon was unlabelled.

In the dinoflagellate experiment, the removal of chlorophyll and POC indicated significant zooplankton grazing. As in the first experiment, ${ }^{14} \mathrm{C}$-activities in the bacterial and dissolved fractions were initially higher in the unscreened than screened samples $(1200 \mathrm{~h}$, Table 2). Initial concentrations of DFPA and thymidine incorporation rate were also higher in the unscreened samples. These data also indicate macrozooplankton grazing enhanced the flow of carbon to the dissolved and bacterial size fractions, although this was not indicated by simply following the accumulation of $\mathrm{DO}^{14} \mathrm{C}$ in the experimental containers.

The thymidine incorporation rates can be converted to conservative estimates of carbon flow (Fuhrman and Azam, 1980) to allow semiquantitative comparisons of this implied carbon flux. The flow of unlabelled DOC implied by thymidine incorporation was higher than the ${ }^{14} \mathrm{C}$-labelled flow to DOC and bacteria in the nanoplankton experiment, but lower in the dinoflagellate

Table 4. Carbon flows to bacteria and $\mathrm{DO}^{14} \mathrm{C}$ after $24 \mathrm{~h}$

\begin{tabular}{|c|c|c|c|c|c|}
\hline \multirow[t]{2}{*}{ Treatment: } & \multicolumn{2}{|c|}{$\begin{array}{l}\text { Thymidine incorp., } \\
\text { rate integrated } \\
\text { over } 24 \mathrm{~h} \text {, as carbon }{ }^{+}\end{array}$} & \multirow{2}{*}{$\begin{array}{c}\text { Bacterial cell } \\
\text { count as carbon" } \\
\text { over } 24 \mathrm{~h} \\
\left(\mu \mathrm{g} \mathrm{C} \mathrm{l}^{-1}\right)\end{array}$} & \multicolumn{2}{|c|}{$\begin{array}{l}{ }^{14} \mathrm{C} \text {-labelled carbon in size } \\
\text { fractions over } 24 \mathrm{~h}\end{array}$} \\
\hline & Total & $\begin{array}{l}\text { Due to } \\
\text { macrozooplankton } \\
\left(\mu \mathrm{g} \mathrm{C}{ }^{-1}\right)\end{array}$ & & Bacteria & DOC \\
\hline \multicolumn{6}{|c|}{ Nanoplankton experiment } \\
\hline supplemented & 8.3 & 4.6 & 7.9 & 1.2 & 3.3 \\
\hline unscreened & 4.7 & 1.0 & 5.3 & $2.0^{\cdots}$ & $3.6^{\circ}$ \\
\hline screened & 3.7 & 0 & 6.5 & 2.0 & 3.9 \\
\hline \multicolumn{6}{|c|}{ Dinoflagellate experiment } \\
\hline unscreened & 8.1 & 4.5 & 19 & 24 & 42 \\
\hline screened & 3.6 & 0 & 18 & 25 & 27 \\
\hline \multicolumn{6}{|c|}{ 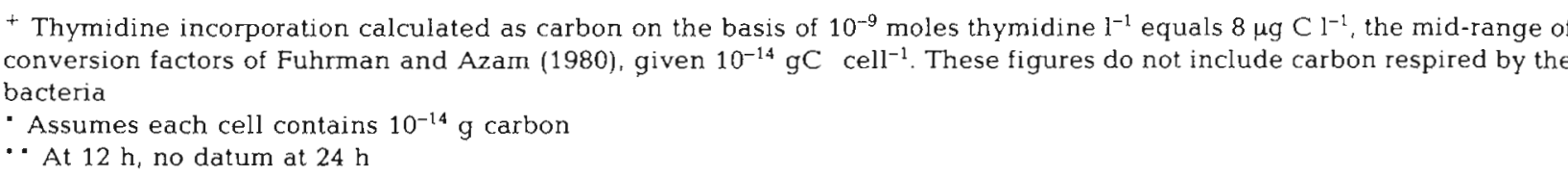 } \\
\hline
\end{tabular}


experiment (Table 4). The increment in the thymidine values of the nanoplankton experiment due to the presence of macrozooplankton, was in the ratio $4.6: 1$ (supplemented \#- \# screened:unscreened \#- \# screened). The ratio of the number of animals in the supplemented to unscreened treatments was $5: 1$. Thus the DOC flow implied by the thymidine data was directly proportional to the number of macrozooplankton present in the vessels, when correction is made for the flux with macrozooplankton removed. For unscreened water samples, the estimated carbon flux to bacteria due to macrozooplankton (Table 4) was 10 and $3 \%$ of the ${ }^{14} \mathrm{C}$ assimilated photosynthetically (Figs. 2 and $4 \mathrm{~A}$ ) in the nanoplankton and dinoflagellate experiments, respectively. Since these are conservative estimates, the actual fluxes are probably higher; inclusion of carbon respired by the bacteria during growth would probably double these estimates.

Calculations of uptake rates for the DFPA and DSAC also revealed relatively high bacterial activities in the dinoflagellate experiment. From 0600-2000 h, DFPA concentrations in the unscreened sample declined at $0.12 \mu \mathrm{g} \quad \mathrm{C}^{-1} \mathrm{~h}^{-1}$; thymidine incorporation rates increased linearly during this period. In the screened sample, the removal of the macrozooplankton was accompanied by an increase in DFPA in the daytime followed by nocturnal decomposition at $0.35 \mu \mathrm{g} \mathrm{C}$ $\mathrm{l}^{-1} \mathrm{~h}^{-1}$. This rapid decline in primary amine carbon was also paralleled by a dramatic increase in the thymidine incorporation rate, i.e. a high bacterial activity, and a rapid loss of DSAC (11.6 $\left.\mu \mathrm{g} \mathrm{C}^{-1} \mathrm{~h}^{-1}\right)$.

The results of the present study indicate that little information was obtained on the role of macrozooplankton grazing in the cycling of DOM through the use of radiolabelled carbon when introduced at the beginning of the experiment. Aside from the first subsampling period, ${ }^{14} \mathrm{C}$-activities in the $\mathrm{DO}^{14} \mathrm{C}$ and bacterial fractions, normalized to phytoplankton activities, indicated little flux of carbon to these sinks as a result of macrozooplankton grazing. However, these results were strongly countered by the thymidine incorporation rates, the small changes in DFPA concentrations over $24 \mathrm{~h}$, and the changes in DSAC concentrations in the nocturnal periods of the dinoflagellate experiment. These data imply relatively larger inputs to the non-labelled carbon pool.

\section{Limitation of the Methods}

Two potential problems are of immediate concern. The first is possible damage to the macrozooplankton from pumping and handling; the second, the use of filter screens in the size fractionation of ${ }^{14} \mathrm{C}$.

The evidence relative to macrozooplankton damage is conflicting. On the one hand, it was clear that grazing occurred, suggesting that at least some of the macrozooplankton were uninjured; on the other, the rate of thymidine incorporation increased to very high levels, suggesting some highly unnatural and possibly

Table 5. Carbon assimilation, chlorophyll a and productivity index ( $\mathrm{mg} \mathrm{C}$ [ $\mathrm{mg}$ chlorophyll $\mathrm{a}]^{-1} \mathrm{~h}^{-1}$ ) in various size fractions of particulate matter. Nominal 'bacteria' size fractions are $0.2-0.6 \mu \mathrm{m}$ (Expt. 1) and $\mathrm{PH}-0.6 \mu \mathrm{m}$ (Expt. 2). PI values based on average chlorophylli a during the experimental periods in parentheses

\begin{tabular}{|c|c|c|c|c|c|}
\hline Time & Treatment & $\mu \mathrm{Cl}^{-1}$ & $\begin{array}{c}\mu \mathrm{g} \mathrm{Chl} . \\
\mathrm{a} \mathrm{l}^{-1}\end{array}$ & \multicolumn{2}{|c|}{$\begin{array}{l}\text { Productivity } \\
\text { index }\end{array}$} \\
\hline \multicolumn{6}{|c|}{$\begin{array}{l}\text { Nanoplankton experiment } \\
\text { Supplemented }\end{array}$} \\
\hline \multirow{8}{*}{2000} & $>0.6$ & 6.14 & 0.132 & 3.88 & \multirow{2}{*}{$(2.57)$} \\
\hline & $0.2-0.6$ & 0.88 & 0.033 & 2.22 & \\
\hline & \multicolumn{5}{|l|}{ unscreened } \\
\hline & $>0.6$ & 10.28 & 0.265 & 3.23 & \multirow[t]{2}{*}{ (3.14) } \\
\hline & $0.2-0.6$ & 2.05 & 0.054 & 3.16 & \\
\hline & \multicolumn{5}{|l|}{ screened } \\
\hline & $>0.6$ & 9.11 & 0.252 & 3.01 & \multirow[t]{2}{*}{$(2.90)$} \\
\hline & $0.2-0.6$ & 1.81 & 0.054 & 2.79 & \\
\hline \multicolumn{6}{|c|}{ Dinoflagellate experiment } \\
\hline \multirow{5}{*}{1200} & \multicolumn{5}{|c|}{ unscreened } \\
\hline & $>3$ & 31.7 & 2.21 & 4.11 & \\
\hline & $1-3$ & 4.90 & 0.161 & 3.42 & \\
\hline & $0.6-1$ & 3.46 & 0.132 & 3.64 & \\
\hline & $\mathrm{PH}-0.6$ & 6.45 & 0.481 & 1.78 & \\
\hline \multirow[t]{5}{*}{1200} & screened & & & & \\
\hline & $>3$ & 30.2 & 1.75 & 4.17 & \\
\hline & $1-3$ & 5.05 & 0.327 & 2.77 & \\
\hline & $0.6-1$ & 3.15 & 0.276 & 2.86 & \\
\hline & PH-0.6 & 5.40 & 0.616 & 1.87 & \\
\hline
\end{tabular}

deleterious effect of pumping, handling or confinement on the plankton populations studied. Nevertheless, other studies with individual animals in controlled laboratory experiments suggest similar DOC flows due to the presence of animals, i.e. $5-17 \%$ of photosynthetic carbon assimilation (Conover, 1966; Lampert, 1978; Copping and Lorenzen, 1980). This suggests the experimental results were not grossly affected by the potential artefacts.

The bacterial size fractions contained chlorophyll a (Table 5). It is not known if this chlorophyll was present in active, small organisms such as cyanobacteria, or in chloroplasts of broken cells. If it is assumed that all the ${ }^{14} \mathrm{C}$-activity in the bacterial size fractions is due to photosynthesis, then bacterial-sized apparent photosynthetic rates per chlorophyll $a$, i.e. the productivity index, can be calculated for the phytoplankton size fraction (Table 5). The productivity index for the bacterial size fraction was only slightly lower than that of 
the larger size class in the nanoplankton experiment but was less than one-half the value of the $>3 \mu \mathrm{m}$ size class of the dinoflagellate experiment. This suggests that the particles passing the $0.6 \mu \mathrm{m}$ filter may be photosynthetically active, but less so than the larger particles. Thus one-half or more of the ${ }^{14} \mathrm{C}$-activity of the bacterial size fraction could be due either to broken cells or to photosynthetic picoplankton (Sieburth et al., 1978) such as cyanobacteria (Waterbury et al., 1979).

\section{Model Predictions}

The conceptual model of Fig. 1 allows several predictions of carbon flows if these flows took place over time with a natural light-dark illumination cycle. A trivial expectation is, for example, that ${ }^{14} \mathrm{C}$-labelled carbon should increase in each compartment over time and this was observed (Figs. 2 and 4). The expectation that macrozooplankton contribute to the flow of ${ }^{14} \mathrm{C}$ labelled carbon was only observed in the first sampling period, although the decline in DFPA concentrations in the dinoflagellate experiment and the thymidine results indicate a flow of unlabelled DOC due to macrozooplankton (Table 4) in proportion to their numbers. The ${ }^{14} \mathrm{C}$-carbon content of the macrozooplankton of nanoplankton experiment indicated only 10 (unscreened) and 38 (supplemented) ng $\mathrm{Cl}^{-1}$ was ${ }^{14} \mathrm{C}$-labelled after $24 \mathrm{~h}$; thus the macrozooplankton assimilated little ${ }^{14} \mathrm{C}$ and contributed little to the flux of radiolabelled carbon to the DOC, the latter result not unexpected considering the small size of the nanoplankton prey. Since fragmentation of phytoplankton usually accompanies ingestion of large prey (e.g. Conover, 1966; Copping and Lorenzen, 1980), little DOM increase would be expected in the nanoplankton experiment.

The incorporation of ${ }^{14} \mathrm{C}$-carbon into the bacterial size fraction should not exceed the carbon content of the bacteria calculated from cell counts. This expectation was realized in the nanoplankton experiment but not in the dinoflagellate experiment, although it is probably within the error inherent in the calculation.

The cropping of microplankton by macrozooplankton might be expected to restrict the rate of increase in microplankton biomass and ${ }^{14} \mathrm{C}$ assimilation and thereby reduce the contribution of $\mathrm{DO}^{14} \mathrm{C}$ by microplankton to DOC and bacterial size-fractions. On the other hand, macrozooplankton releases may be a principal route of nutrient supply for phytoplankton growth in nutrient-depleted waters (Roman and Rublee, 1980); thus photosynthetic rates per chlorophyll a might be higher in unscreened than in screened water samples. This was suggested in the nanoplankton experiment (Table 5) where the productivity index (PI) at $2000 \mathrm{~h}$ was proportional to the number of macrozooplankton present.

The model implies that bacterial biomass and/or activity increase in response to increased carbon flow to DOC (unless microzooplankton cropping of bacteria is overriding). This was confirmed in the ${ }^{14} \mathrm{C}$ bacterial size-fractions, changes in the DFPA concentrations, and the thymidine data, but bacterial counts showed little increase. Perhaps bacterial numbers were maintained by microzooplankton grazing, but we have no data on this prospect.

Since photosynthesis is limited to the day, nocturnal losses of ${ }^{14} \mathrm{C}$-carbon in the particulate fractions were expected. This was noted in the $>0.6 \mu \mathrm{m}$ fraction of the nanoplankton experiment (Fig. 2), but not in the dinoflagellate experiment (Fig. 4), where the largest such loss was in the DOC (DFPA, DSAC) fraction. In both experiments, the ${ }^{14} \mathrm{C}$ flow to the bacterial size fraction slowed but remained positive at night. This held also for the $\mathrm{DO}^{14} \mathrm{C}$ fraction except as noted above. Large nocturnal losses of DFPA-C were recorded in the screened samples of dinoflagellate experiment $>$ $340 \mathrm{ng} \mathrm{C}^{-1} \mathrm{~h}^{-1}, \mathrm{t}_{3}$ to $\mathrm{t}_{4}$ ). The $\mathrm{DO}^{14} \mathrm{C}$ and DFPA data suggest that a relatively large amount of material became labelled during the day that could fuel continued bacterial growth at night. That the $D \mathrm{O}^{14} \mathrm{C}$ pool was not depleted at night implies continued inputs from the microplankton.

In summary, our results indicate that zooplanktonmediated carbon fluxes from phytoplankton to the DOC pool do indeed occur. Whether or not such fluxes can be observed by following the fate of photosynthetically fixed ${ }^{14} \mathrm{C}$-bicarbonate may depend on the populations present. Indirect measurements (e.g. ${ }^{3} \mathrm{H}$-thymidine incorporation, measurements of DSAC and DFPA) provide independent evidence for the existence of such fluxes.

Acknowledgements. A. F. Carlucci, E. H. Renger and M. M. Mullin assisted and advised on the experiments at sea. F. M. $\mathrm{H}$. Reid and J. R. Beers examined the preserved samples for phytoplankton and ciliate identifications. D. Osborn and J. Stearns typed several. drafts of the manuscript. We thank them for their aid. Financial support for the work was provided by U.S. Department of Energy Contract DE-AMO 3-76SF00010.

\section{LITERATURE CITED}

Azam, F., Hodson, R. E. (1977). Size distribution and activity of marine microheterotrophs. Limnol. Oceanogr. 22: 492-501

Berman, T., Holm-Hansen, O. (1974). Release of photoassimilated carbon as dissolved organic matter by marine phytoplankton. Mar. Biol. 28: 305-310

Bohrer, R., Sellner, K. G. (In prep.). The effects of feeding on zooplankton metabolism. I. A comparison of excretion 
products in Calanus finmarchicus and Metridia lucens as a function of herbivorous and carnivorous feeding

Burney, C. M., Sieburth, J. McN. (1977). Dissolved carbohydrates in seawater. II. A spectrophotometric procedure for total carbohydrate analysis and polysaccharide estimation. Mar. Chem. 5: 15-28

Conover, R. J. (1966). Feeding on large particles by Calanus hyperboreus (Kroyer). In: Barnes, H. (ed.) Some contemporary studies in marine biology. Allen and Unwin, Ltd., pp. $187-194$

Conover, R. J. (1979). Secondary production as an ecological phenomenon. In: Van de Spoel, S., Pierrot-Bults, A. C. (eds.) Zoogeography and diversity of plankton. Halsted Press, New York, pp. 50-86

Conover, R. J., Francis, V. (1973). The use of radioactive isotopes to measure the transfer of materials in aquatic food chains. Mar. Biol. 18: 272-283

Copping, A. E., Lorenzen, C. J. (1980). Carbon budget of a marine phytoplankton-herbivore system with carbon-14 as a tracer. Limnol. Oceanogr. 25: 873-882

Corner, E. D. S., Head, R. N., Kilvington, C. C., Pennycoick, L. (1976). On the nutrition and metabolism of zooplankton. X. Quantitative aspects of Calanus helgolandicus feeding as a carnivore. J. mar. biol. Ass. U. K. 56: 345-358

Corner, E. D. S., Newell, B. S. (1967). On the nutrition and metabolism of zooplankton. IV. The forms of nitrogen excreted by Calanus. J. mar. biol. Ass. U. K. 47: 113-120

Dagg, M. J. (1974). Loss of prey body contents during feeding by an aquatic predator. Ecology 55: 903-906

Eppley, R. W., Renger, E. H., Venrick, E. L., Mullin, M. M. (1973). A study of plankton dynamics and nutrient cycling in the central gyre of the North Pacific Ocean. Limnol. Oceanogr. 18: 534-551

Fiedler, P., Huntley, M. (1981). Dinoflagellate blooms escape zooplankton grazing. Nature, Lond. (Submitted)

Fuhrman, J. A., Ammerman, J. W., Azam, F. (1980). Bacterioplankton in the coustal euphotic zone: Distribution, activity and possible relationships with phytoplankton. Mar. Biol. 60: 201-207

Fuhrman, J. A., Azam, F. (1980). Bacterioplankton secondary production estimates for coastal waters of British Columbia, Antarctica, and California. Appl environ. Microbiol. 39 (6) : 1085-1095

Hobbie, J. E., Daley, R. J., Jasper, S. (1977). Use of Nuclepore filters for counting bacteria by fluorescence microscopy. Appl. environ. Microbiol. 33: 1225-1228

Jawed, M. (1969). Body nitrogen and nitrogenous excretion in Neomysis rayii and Euphausia pacifica. Limnol. Oceanogr. 14: 748-754

Johannes, R. E., Webb, K. L. (1965). Release of dissolved amino acids by marine zooplankton. Science, Wash., D.C. 150: 76-77
Johannes, R. E., Webb, K. L. (1970). Release of dissolved organic compounds by marine and fresh water invertebrates. In: Hood, D. W. (ed.) Organic matter in natural waters. Inst. Mar. Sci., Univ. Alaska, Occas. Pap. No. 1, pp. $257-273$

Lampert, W. (1978). Release of dissolved organic carbon by grazing zooplankton. Limnol. Oceanogr 23: 831-834

Le Borgne, R. P. (1973). Etude de la respiration et de l'excrétion d'azote et de phosphore des populations zooplanctoniques de l'upwelling mauritanien (mars-avril 1972). Mar. Biol. 19: 249-257

Marshall, S. M., Orr, A. P. (1962). Food and feeding in copepods. Rapp. P.-V. Réun. Cons. Perm. int. Explor. Mer 153: $92-98$

Mayzaud, P. (1973). Respiration and nitrogen excretion of zooplankton. II. Studies of the metabolic characteristics of starving animals. Mar. Biol. 21: 19-28

North, B. B. (1975). Primary amines in California coastal waters: Utilization by phytoplankton. Limnol Oceanogr. 20: 20-27

Roman, M. R., Rublee, P. A. (1980). Containment effects in copepod grazing experimennts: A plea to end the black box approach. Limnol. Oceanogr 25: 982-990

Sharp, J. H. (1974). Improved analysis for 'particulate' organic carbon and nitrogen from seawater. Limnol. Oceanogr. 19: 984-989

Sieburth, J. McN., Smetacek, V., Lenz, J. (1978). Pelagic ecosystem structure: Heterotrophic compartments of the plankton and their relationship to plankton size fractions. Limnal. Oceanogr 23: 1256-1263

Star, J. L., Mullin, M. M. (1979). Horizontal undependability in the planktonic environment. Mar. Sci. Commun. 5: $31-46$

Strickland, J. D. H., Parsons, T R. (1972). A practical handbook of seawater analysis, 2nd ed., Bull. Fish. Res. Bd Can., No. 167

Szyper, J. P., Hirota, J., Caperon, J., Ziemann, D. A. (1976) Nutrient regeneration by the larger net zooplankton in the southern basin of Kaneohe Bay. Pacif. Sci. 30(4): 363-372

Waterbury, J. B., Watson, S. W., Guillard, R. R., Brand, L. E. (1979). Widespread occurrence of a unicellular, marine, planktonic cyanobacterium. Nature, Lond. 277: 293-294

Webb, K. L., Johannes, R. E. (1967). Studies of the release of dissolved free amino acids by marine zooplankton. Limnol. Oceanogr. 12: 376-382

Wheeler, P., North, B., Littler, M., Stephens, G. (1977). Uptake of glycine by natural phytoplankton communities. Limnol. Oceanogr. 22: 900-910

Williams, P. J. le B., Yentsch, C. S. (1976). An examination of photosynthetic production, excretion of photosynthetic products, and heterotrophic utilization of dissolved organic compounds with reference to results from a coastal subtropical sea. Mar. Biol. 35: 31-40 